\title{
Industrial Corridors and Policy Imperatives for Their Success
}

\author{
Dr. Pardeep Kumar \\ MGM Institute of Management Aurangabad (Maharashtra)-431003
}

\begin{abstract}
Performance indicators or manufacturing industry like growth rate, exports, investments, employment generation, drawing FDI and the labour productivity etc. showed a continuous decline in the last five years. Though a very comprehensive policy framework exists but lackadaisical implementation, political opposition, lack of infrastructure, bureaucratic mind set, scams and corruption have hit the performance adversely. In the last decade or so, Govt of India adopted the model of setting up industrial clusters and Special Economic Zones (SEZs). Success of this model adopted by other countries and their failure in India points out the weakness in the policy framework and implementation. Industrial corridors in Japan and China have flourished as they made policies and implemented the same vigorously. Govt of India is now setting up industrial corridors especially Delhi-Mumbai Industrial Corridor (DMIC) and is planning to set up National Investment and Manufacturing Zones (NIMZs) as mentioned in the Industrial Policy 2011. India needs to take a cue from other countries and review its policies maintaining transparency and accountability for ensuring the success of these industrial aggregations. Sustainability and inclusiveness are two more requirements of the modern age. Structural reforms, innovation and modernization can produce competitive advantage thereby ensuring the success of industrial corridors. Policy reforms in taxation, land acquisition and land use, centre state and public private partnerships and division of responsibilities, easing business environment for more inflow of FDI, equity sourcing at competitive rates, power, optimum utilization of scarce natural resources, environmental considerations, skill development, use of abundant human resources and knowledge creation by $R \& D$, infrastructure creation are key themes on which the policies must be reviewed for the success of industrial corridors/clusters. Many of the Indian industrial policies are comparable with other countries but vigorous implementation and accountability are lacking. Policy implementation is more important for this purpose.
\end{abstract}

Key Words: Socialist Marketing, Democratic Marketing, Industrial Corridors, Industrial Aggregations, National Investment and Manufacturing Zones (NMIZs)

\section{Introduction}

Since 2007, two issues which captured maximum attention were the declining growth of value added in industrial sector which hovered around 3-3.5 percent in 2013-14 with manufacturing sector at 2.7 to 1.9 percent in 2011-2013. Gross capital formation ratio contracted by 8.7 percent in 2010-2011 as compared to 0.3 percent in 2008-2009 (India Budget, 13-14). Rate of setting up new factories slumped to less than 3 percent from 33 percent in 2009-2011. New investments fell continuously since 2007. On the other hand, Govt of India (GoI) has approved National Manufacturing Policy, 2011 (NMP-2011) with provisions for creation of industrial aggregations. GoI has made an agreement with Govt of Japan (GoJ) for a ambitious mega project of establishing a $1483 \mathrm{Km}$. long Delhi-Mumbai Industrial Corridor (DMIC) and three other industrial corridors are also being planned. DMIC involves setting up Industrial Areas (IAs) and Industrial Regions (IRs) and smart cities for establishing ultramodern 'global manufacturing and trading hubs'. Despite the comprehensive policies, overall performance of manufacturing industry, industrial clusters and Special Economic Zones (SEZs), did not achieve the laid down objectives as compared to other countries. The lackluster performance of Indian industry despite there being a competitive policy regime calls for a review of policies and their implementation so that the industrial performance is improved.

\section{The Problem}

India has undertaken to develop industrial corridors as engines of growth and employment, but performance indicators reveal that Indian industry especially the Special Economic Zone have not performed well as compared to other countries. There is requirement to analyze what policy imperatives are necessary to ensure the success of industrial corridors and the industry in general.

\section{Objectives Of The Paper}

1. Models of industrial development and Concept of industrial aggregations and corridors.

2. Industrial policy regimes set up by China and India.

3. Recommended policy imperatives for success of industrial aggregations and corridors. 


\section{Research Methodology}

The paper is based on the secondary sources. The data has been taken from various govt publications, books, journals, newspapers, magazines and websites.

\section{Models Of Industrial Development And Concept Of Industrial Corridors}

5.1 In order to achieve desired industrial production, raise industrial survival and its competitiveness, the govts play a major role by using their authority and resources and by formulating and implementing suitable policies. The govts customize policy instruments to fit the priorities and needs of industries. The goals may differ overtime and be multiobjective like full employment, export promotion, import restriction and technology and skill upgradation. The govts invoke policy instruments like subsidies, tax sops, infrastructure build up, import restrictions, R\&D subsidies and employment programmes etc.

The govts attempt to achieve the goal of industrialization by political economy with reliance on centralized planning and administrative guidance for control and wide state intervention. This may be done by achieving large economies of scale, improving process technologies, investment in new capacities and better process technologies. State ownership in key industries is kept smaller and focus may be success of some but not all industries. This model was followed by Japan to industrialize at a much faster pace after the Second World War. The Korean model was based on reliance on innovations and its roots in scientific and technological capacities. Other ingredients of this model being assessment of assets, institutionalized policies needed to nurture and innovation based development strategy. Cooperative agreements between science and technology institutions, universities and govt were also encouraged (Almas Heshmati, 2007). China adopted the model of 'market socialism'. Deng Xiaoping's version of 'market socialism' envisaged a slow, controlled opening of the Chinese economy to the outside world. Four large coastal areas i.e. Shenzhen, Zhuhai, Shantou, and Xiamen in the Guangdong and Fujian Provinces were allocated to become special economic zones (SEZs). Subsequently, China listed additional areas as SEZs and special development areas. China exploited the fact that co-located industrial areas improve their competitiveness by business value chain, lower logistics costs and networking that encourages knowledge and technology creation. The SEZs on the eastern coast performed amazingly well and set up an example of a new industrial model in the form of industrial clusters located along a high mobility communication artery from Xiamen to Dalian via Hangzhou and Shanghai. Japan had adopted a somewhat similar model by setting up Tokyo- Nagoya-Osaka belt of industrial cities which accommodates 90 million people i.e. 70 percent population of Japan. This is a high mobility corridor which affords many advantages to industrial clusters. Recognizing the requirement of providing a level playing field between exports and imports, India had adopted another model wherein some industrial units were made export oriented units with special privileges and it had led to setting up of special export processing zones (EPZs). The first EPZ was set up in Kandla in the mid sixties. The special Economic Zones Act, 2005, was passed by Indian Parliament in May, 2005. Thereafter a number of SEZs were set up but these were not connected with special roads or rail.

5.2 Industrial corridor thus established by Japan and China afforded numerous advantages such as improved supply chain, easy access to markets, availability of talent and substantially lower logistics costs. Industrial clusters overcome many infrastructural bottlenecks also as efficiency is achieved by special financial, regulatory and statutory provisions conducive to industry. Laws pertaining to land ownership, labour, FDI and tax concessions are more flexible which ensure success as in the case of SEZs in China. Policy reforms like fixing of clear targets of exports and imports, bringing in FDI and employment had put great deal of pressure on the shoulders of govt and other officials who were held accountable (Douglas Zhihua, 2011). This was the main reason of success behind Chinese model. With the advantages brought out above, the model of industrial clusters located along high mobility communication arteries was considered viable and was adopted by a number of countries including Pakistan, Iraq, Belarus and Indonesia etc.

5.3 Selection of Suitable Industrial Model and Expected Deliverables. Choice of a particular model is made based on many factors like investment decision, selection of lines of import substitutions and new export, choice of technology, location choices involving production and distribution, transport route selection, economies of scale and indivisibilities (Thomas Vietorisz, 1968). In addition to this, some modern ideas like sustainable development and inclusive growth would merit consideration. Sustainable development should accomplish three things. Firstly, it should encourage markets (economic dimension). Secondly, it should create employment (social dimension) and thirdly, it should protect environment by functioning in limits of ecosystem (environmental dimension).

Many a countries have selected identical deliverables and policy framework for industrial clusters and SEZs. Instrument employed to achieve these objectives are generally similar. Policies followed in this regard by China include i) special tax incentives for FDI ii) easy availability of land iii) greater independence in international trade activity iv) more reliance on foreign capital for creating infrastructure v) incorporating 
economic forms of sino-foreign, joint ventures , partnerships and wholly foreign owned enterprises. vi) products are export oriented and vii) economic activity is driven by market forces.

Performance of industrial clusters (SEZs) and industry in general in India remained quite low as compared to China especially when the objectives and instruments for achieving them were almost identical. Comparative performance is given in Table 1 and Table 2 illustrates the same.

Table 1: Comparison Of Exports, Trade Surplus And Labour Productivity** Between India And China*

\begin{tabular}{|c|c|c|c|c|c|c|c|}
\hline Country & 2002 & 2003 & 2004 & 2005 & 2006 & 2007 & 2008 \\
\hline \multicolumn{8}{|c|}{ Share of World Exports (\%) } \\
\hline India & 0.01 & 0.01 & 0.01 & 0.01 & 0.01 & 0.01 & 0.01 \\
\hline China & 0.05 & 0.06 & 0.06 & 0.07 & 0.08 & 0.09 & 0.09 \\
\hline \multicolumn{8}{|c|}{ Trade Surplus India and China (Export-Import/GDP) (\%) } \\
\hline India & & 1.3 & 14.5 & 11.3 & 6.7 & 17.5 & 10.1 \\
\hline China & & 8.6 & 17.8 & 19.1 & 10.9 & 25.0 & 16.1 \\
\hline \multicolumn{8}{|c|}{ Total Labour Productivity (1000 USD) } \\
\hline India & 10.7 & 12.6 & 14.2 & 15.8 & 16.6 & 19.2 & 29.5 \\
\hline China & 56.1 & 66.6 & 79.0 & 93.7 & 111.1 & 131.8 & 156.4 \\
\hline
\end{tabular}

*Source. Wei Tian, Miaoje Yu (2012). China and India. Available at mjyu.ccer.edu.cn/JCGE_Tian_Yu.pdf.

** Labour Productivity. It is the total factor productivity (TFP) as it considers a variety of factors such as labour, capital, and intermediate materials. It is measured by industrial output divided by number of employees in that sector.

Table 2: Comparative Performance Of Sezs Of India \& China

\begin{tabular}{|l|c|c|c|c|c|c|}
\hline \multicolumn{1}{|c|}{ Country } & $\mathbf{2 0 0 0 - 0 1}$ & $\mathbf{2 0 0 6 - 0 7}$ & $\mathbf{2 0 0 7 - 0 8}$ & $\mathbf{2 0 0 8 - 0 9}$ & $\mathbf{2 0 0 9 - 1 0}$ & $\mathbf{2 0 1 0 - 1 1}$ \\
\hline \multicolumn{7}{|c|}{ Exports from Chinese and Indian SEZs (Bn USD) } \\
\hline China@ & 27.93 & 175.9 & 217.2 & 213.5 & \multicolumn{2}{c|}{ Not Available } \\
\hline India* & 1.930 & 7.5 & 15.1 & 24.9 & 46.9 & 68.65 \\
\hline \multicolumn{7}{|c|}{ Growth in Value of Merchandise Exports Measured in USD** } \\
\hline China & 8.6 & 17.8 & 19.1 & 10.9 & 25.0 & 16.1 \\
\hline India & 1.3 & 14.5 & 11.3 & 6.7 & 17.5 & 10.1 \\
\hline \multicolumn{7}{|c|}{ Employment Generated by Indian and Chinese SEZs (000s) } \\
\hline China & 4058.6 & 5250.0 & 5402.65 & \multicolumn{3}{c|}{ Not available } \\
\hline India^ & 95.04 & 178.0 & 280.8 & 336.2 & Not available \\
\hline
\end{tabular}

Source: * www.sezindia.nic.in/about_ep.asp accessed on 08 Feb 14(Converted to USD using dollar exchange rate of March of that particular year), @Yue-manYeung et.al. (2009), **WTO Trade Data base, ${ }^{\wedge}$ Ministry of Commerce, GoI, Annual survey of industries, various issues.

India had identified the potential and effectiveness of EPZs model in promoting exports with Asia's first EPZ established in Kandla in 1965, with the view to i) overcome shortcomings experienced on account of multiplicity of controls and clearances ii) absence of world class infrastructure and iii) to overcome problems of unstable fiscal regime failing to attract FDI.

Though India formulated competitive tax related policies like China, had better depth and breadth of industry, higher content of low end labour and more stable fiscal policy and markets yet its industrial performance did not match China.

\section{Policy Regime Setup By Various Countries}

6.1 Policy Framework Adopted by China. Policy of 'growth first equity later' and deregulation of responsibilities to cities, municipalities and upgradation of status to provinces helped in setting up sound regulatory and administrative environment. The officials expressed far more concern in what outsiders bring to the counry in terms of jobs, technology and forex (Wilfried Vanhonacker, 2004). Success of the SEZ model adopted by the Chinese is largely attributable to the policy of gradualism with an experimental approach with a strong commitment, active pragmatic facilitation of state and top leadership, preferential policies, broad institutional autonomy, staunch support and proactive participation of govt. Public private participations (PPP), FDI and investment of Chinese diaspora also played a vital role. Clear goals and vigorous benchmarking, monitoring and competition, business value chain and social network and technology, learning and upgradation were well incorporated in system in a very effective manner (Douglas Zhihua, 2011). In addition to this, enactment of Land Use Rights (LURs) which is in the hands of CCP, removed many hurdles in establishment of industrial enclaves and it generated assets to give subsidy to FDI and exporters (Arvind Virmani, 2006). With liberal policies to attract FDI in terms of capital subsidies and relaxed labour laws, investors from Hong Kong, Macau and Taiwan moved to China. FDI was facilitated by streamlining administration control, consensual tax rates, breaks and exemptions and preferential fee for land, low rates on import, low rent on business accommodation, flexible hiring and firing of workers, depreciation allowances, favourable arrangements in project duration etc. Corporate tax on FDI was 15 percent as compared to 30 percent for domestic. FDI was exempted from local income tax. Listing of govt owned companies and banks on foreign /domestic stock 
exchanges was a clever step to attract foreign equity capital to finance investment. In case of high tech / non labour intensive industry, low cost loans for non-labour intensive exports and zero or negative effective cost were given. These subsidies are transferred through below cost prices in to explicit subsidy to FDI and export in hi-tech industry. This attracts FDI and capital and skill intensive exports are created. This accounts for big FDI differential between India and China. Control of enterprises is a unique feature in China. Control is exercised by CPP over state or govt owned enterprises, town and village enterprises (TVEs) and PSUs even the ones listed on Hong Kong exchange. CPP appoints top management in listed companies, co-operatives, TVEs and state owned enterprises. Village committees perform govt functions but village officials are not govt servants. Capital has been channelized to desirable sectors by a number of policy reforms like capital cost which can vary for different borrowers. Non-performing assets have no bearing on grant of loans to State owned Enterprises because credit can be given for any activity which is useful. Below market rates are a common phenomenon. CCP controls banks even if some shares ae owned by foreign banks. Foreign exchange swap and devaluation of yuan dual exchange rate integrated in 1994 and current account convertibility were done in 1995 to promote exports. CPP controls labour unions through 'Hakou' system which helps to ensure availability of labour. Provision of legal, accounting, marketing, skill training and management counseling services helped to create a business friendly ecosystem. Vocational education, R\&D, and skill development at universities strengthened knowledge and technology creation.

Effectiveness of local govt by the way of offering incentives, approvals and licences assisted fast execution and elimination of internal rivalry (Ming Zeng and Peter J. Williamson, 2004). Countries like China, Thailand and Philippines have developed despite corruption whereas India has not. This projects a very poor image of the country and affects attractiveness index adversely. Lethargy and inaction is much more harmful than financial corruption (bribery) in low and middle income countries. But that is not the case with China. This highlights the vigour of implementation of policies and accountability of officials and thus the govt.

\subsection{Policy Framework of India}

Consistently lower growth rate of manufacturing sector, was attributable to sluggish growth in investment, low margins in corporate sector, deacceleration in rate of growth in credit flow, fragile global economy, inadequate infrastructure, complex regulatory environment, slow project implementation and low availability of skilled manpower. Considering this, GoI launched three key initiatives to boost manufacturing namely approval of NMF, 2011, setting up of DMIC, FDI policy initiatives and setting up of e-biz project to promote ease of doing business. The aim is to enhance the share of manufacturing in GDP by to 25 percent from stagnated 15-16 percent, within a decade. It also envisages creating 100 million jobs towards the greater requirement of creating 220 million jobs by 2025 for its growing population. Stagnation in growth has been attributed to inadequate infrastructure, complex regulatory environment, and inadequate availability of skilled manpower. The new manufacturing policy is based on principle of industrial growth in partnership with states. Centre govt will create the enabling policy framework; provide incentives for infrastructure development on PPP through appropriate financing instruments. Manufacturing is to be sustainable, environment friendly, based on optimum utilization of energy and natural resources and restoration of eco-systems.

Six objectives of the manufacturing policy include i) increasing manufacturing sector growth by 12-14 percent ii) increasing rate of job creation (100 million by 2022) iii) creation of skill sets iv) to make growth inclusive v) to increase value addition and depth in manufacturing vi) ensure sustainability.

These objectives are planned to be achieved by nine policy instruments i.e. i) rationalization of regulation ii) speedy exit for sick units iii) financial and institutional mechanisms for technical development iv) individual training and skill development v) incentives for SMEs vi) earmarking special focus sectors vii) leaving infrastructure deficiency and govt procurement viii) clustering and aggregation of industry (NMIZs) and ix) trade policy.

NMP, 2011 (DIPP, 2011) envisages promotion of clusters and aggregations in the form of NIMZs. Out of 12 NIMZs decided so far, 8 are located along DMIC and one each will be located at Nagpur, Tumkur, Chitoor and Medak. Four industrial corridors have been approved as described below:

i) Amritsar-Delhi-Kolkata Industrial Corridor: It was approved in April 2014 and would cover 5.5 lakh sq $\mathrm{Km}$. in seven states. It would use both PPP and non PPP approach. Each state will be encouraged to make industrial cluster of $10 \mathrm{sq}$. Km. each.

ii) Mumbai- Bangalore Industrial Corridor: In Feb 13, GoI and UK joined hands to set up $1000 \mathrm{Km}$. long corridor called Peninsular Regional Industrial Development Corridor (PRIDe). A NIZM will be established at Timkur.

iii) Chennai- Bangalore Corridor. Work on this $560 \mathrm{Km}$. long corridor was initiated in Dec 2011. This is also being setup with the help of GoJ. 
iv) DMIC. DMIC is an ambitious mega infrastructure program (USD 90 billion or Rs. 4, 23,000 Crore to be financed jointly by GoI and GoJ) aiming to develop new industrial cities as 'smart cities' and converging next generation technologies across infrastructure sectors. It involves construction of $1483 \mathrm{Km}$ of six lane multi modal and multi axle, intersection free expressway from Delhi (Dadri) to Mumbai (JNPT). It also incorporates construction of nine mega Investment Regions (IRs) of about 200-250 sq km each and 15 Industrial Areas (IAs) of $100 \mathrm{Sq} \mathrm{Km}$. each, three ports, six airports and $4000 \mathrm{MW}$ power plant. Several industrial estates and clusters, industrial hubs with top of the line infrastructure would be developed along this corridor and it would provide transparent and investment friendly facility regime. A band of $150 \mathrm{~km}$ (Influence region) has been chosen on both sides of the freight corridor to be developed. DMIC is to achieve double employment potential in five years (14.87\% CAGR), triple industrial output in five years (24.57\% CAGR) and quadruple exports from the region in five years (31.95\% CAGR). (www.delhimumbaiindustrialcorridor.in). DMIC project requires an investment of USD 90 billion which will be met through PPP (potential $75 \%$ ) and through budgetary resources. As per terms and conditions, Japan Bank for International Cooperation (JBIC) has taken $26 \%$ equity in DMIC and the GoJ has created USD 4.5 billion facility for the project. Rate of interest for funds offered through untied loan could be $1.2 \%$ with a moratorium of 3 years and a repayment period of 10 years.

\section{Recommended Policy Imperatives For The Success Of Industrial Aggregations And Corridors.}

Being a democratic country, India cannot adopt a system of 'market socialism' and Land Use Rights as done by China. China being a communist led govt, they are less subjected to short-term pulls and pressures than a democracy as in India. Once the party decides that an issue is of interest to them, they use all resources and focus everything on that (Charan Singh, 2013). This has ensured that the ease of doing business in China is high and the environment is business friendly. On the other hand corporate tax and tax holiday incentives in India are better than China. Indian capital markets are more transparent and predictable. Abundant human resource is available for low end manufacturing. But still India has been reported to be at $134^{\text {th }}$ place out of 189 countries in ease of doing business. Other aspects where it holds poor positions are enforcing contracts $\left(186^{\text {th }}\right)$, dealing with construction permits $\left(182^{\text {nd }}\right)$ and starting a business $\left(179^{\text {th }}\right)$. This speaks volumes for poor FDI and the reason for withdrawal of many companies from India.

Experience suggests that success/failure of an economic zone is linked to the policies, incentives, infrastructure and the way it is located (FIAS, 2008). With policy provisions being there, the problems appear to be in the implementation. Therefore, it will be prudent to incorporate lessons learnt from worldwide experiences for successful implementation of industrial corridors within Indian systems and conditions. Two important aspects of policy paradigm must be considered. Firstly the policy frame work for DMIC has to address two phases namely construction of DMIC and operationalising the IAs and IRs followed by sound policies for making the business environment smooth and friendly. Secondly, the focus of policy imperatives should be on creating knowledge and manpower intensive manufacturing economy keeping sustainability and inclusiveness at the centre stage. Policy paradigm regarding industrial corridors is recommended to address and include the following provisions:

7.1 Policies of fiscal incentives, restrictive controls on activity and regulations must be transparent, unambiguous and there should be no requirement for govt interference at every step. When the policy has been articulated, its implementation should be left to the administrative ministers (Sojin Shin, 2014). Clear policies related to tax repatriation of projects, FSI, labour contracts in corridors, social security, common tax rates and breaks to domestic and foreign companies should be firm \& business friendly. "In the last five years we have lost our way. We are in a transition phase of creating templates for regulations and resources utilization. If we want to be transparent capital economy, we need institutional templates." (Anand Mahindra, 2014).

7.2 Policy framework must encourage investment and must provide long term loans at reasonable rates through public investment and different loan programmes and credit guarantees. India should not be averse to urbanization and must be promoted with incentives and investments (Amitab Kant, 2013)

7.3The decline in capital formation, rate of setting up new industry and rate of growth to 4.5percent is due to policy inaction. Lack of determined implementation, slowing down of Indian economy, rising cost of raw material, land acquisition, inflation, delay in getting regulatory clearances, governance issues, infrastructure constraints, high interest rates, decline in exports, policy conundrums (licenses, permissions and clearances) and availability of required land. Adequate steps would be required for improvement in the investment climate and investor sentiment by reviewing policy handle including grant of clearances. 
7.4 Inflow of FDI. Policy of hoarding foreign exchange by Indian govts and failure to pursue any scheme for promoting FDI resulted in a situation where companies could not even access advanced technology (Sojin Shin, 2014). In the absence of policy framework, investment in SEZs remained laggard (Aradhna Aggarwal, 2007). Now the FDI policy has been much liberalized in single and multibrand retail, civil aviation, broadcasting, teleports and mobile TV. Still we have a suspicious attitude towards companies and the private companies when most of the world which attracts the FDI has positive attitude. Unfortunately our bureaucracy is not trained to think like that. These indices of governance, of corruption, or whatever one wants to call, affect both domestic investment and FDI. This would require i) identification of sources of FDI and giving them all support like China did ii) being more clear on external objectives ii) coordinate across departments which deal with outside world. iii) attracting Indian diaspora for investment in india by preferential policies and financial support to NRIs and vi) macro-environment should allow flourishing of the industrial enterprise.

7.5 Speculative and non-productive investment activities must be discouraged through to avoid wasting scarce resources, concentration of investment and creation of bubbles e.g. in real estate markets (Almash Heshmati, 2007).

7.6 Indian Manufacturing Value added (MVA) as share of GDP has remained at around 15 percent and is Country's Industrial Performance Index (CIP) is at $42^{\text {nd }}$ place among 118 countries. Manufacturing sector need dynamism and technical sophistication to lead in manufacturing. These points out the flaws in R\&D and innovation. Policy provision must be made to support education and R\&D by linking it to tax incentives carrying out cooperative projects and facilitate transfer of technology. World class institutes of science and technology should be set up in IAs and IRs for research and skill development. Provisions regarding copyrights, setting up technology, innovation centers to develop new products and to provide technical and innovative services below market prices, preferential policies for highly qualified persons/domain experts and companies possessing better and latest technology in terms of land allotment, tax exemptions and better loans should be enforced. Universities must be encouraged to help with research in production, processing, pollution control and testing services through Research Institutes and design centers. World class universities to be invited to open campuses in industrial clusters.

7.7 Value addition component and employment generation potential in clusters is high. Human capital must be treated as the USP of Indian industrialization. Policies should be based on optimal utilization of human capital by the way of skill development, creating opportunities for mass employment, urbanization and relocating workers. Govt should financially support training in the application of technologies and development of a capital goods sector and promote the process of accumulating human capital and institutional infrastructure to master the transferred technologies leading to increase in technology absorption. Seven skill development sectors planned in DMIC is a good step but their quality control and operationalisation should be done timely and meticulously.

7.8 Land Acquisition. This is one of the major challenges for setting up the industrial corridors (Amitab Kant, 2013) and one of the major reasons for failure of SEZs was the entry of private developers and land scams. (Vinay Tyagi et. al. 2007). Process of land acquisition based on 1884 land acquisition law is unilaterally in favour of the govt. In India $60 \%$ of the population has rights over only $5 \%$ of the country's land and $10 \%$ of population controls 55\% of land. (DLRP 2013). Cases of corruption by govt officials, politicians and middlemen make things worse. Condition of evictees in earlier land acquisition cases is very pitiable in most of the cases. Agitations and attempts to evict the MNCs inhibit FDI and foreign investors tend to withdraw. In order to make DMIC a success, barren lands should be used for IRs. Ousted farmers must be made stakeholders and further acquisition should be carried out under the provisions of Land Acquisition Rehabilitation and Resettlement Act2013. State govts must carry out this task efficiently and timely. Issue of land acquisition is likely to be very high on agenda of new government (Hindustan Times, 21 May 14).

7.9 Infrastructure remains another major weakness. Though industrial corridors are planned to have ultramodern cities, without commensurate road, rail, air, port, power, education, water, banking and other infrastructure in adjoining areas, the industry cannot create attractive friendly for investment. Coal and mining sector also need to be reinvigorated. Requirements of land, water and natural resources will be required to be worked out meticulously. 
7.10 State govts and Local authorities should set standards for investment quality to ensure efficiency including better use of land and less pollution. This needs to be strengthened by strong regulatory regime, legal system, evaluation systems for public spending and social safety net.

7.11 Policies must be in place for Quality Control and Inspection systems to ensure product quality must be incorporated at the local govt level. Govt must provide assistance in IT, IPR Protection, professional training, testing and certifications etc. IRs must provide social services, health, education and public transport services. IRs must be attractive for foreign companies in the sense of provision of social infrastructure and services.

7.12 Multiple approvals and operational restrictions are required to be removed. Single window clearance systems are not working. This is one of the major implementation problem. Industrial manufacturing failed to take off due to lack of clearances form other ministries (G.S. Kaura, 2014). Invest India scheme set up by DIPP and FICCI for granting single window clearances for foreign investors is a good initiative. E-biz project is undertaking national e-governance plan (NeGP) for online clearances must be made functional.

7.13 Corruption Index. Asian economies have been characterized by fairly high levels of (perceived) corruption. Corruption Perception Index (CPI) for 2013, based on a much larger sample of 177 countries, India occupies $94^{\text {th }}$ rank. Public institutions should be supportive and solve problems rather than creating problems in bureaucracy, corruption and inefficiency. Anti corruption policies and laws need review.

\section{Conclusion}

Industrial corridors and NIMZs planned in India are mega-projects and futuristic vehicles of economic growth. Projects of this mammoth nature need thorough visualization, planning and extraordinary meticulous execution. Comprehensive policy frameworks and its implementation are mandatory for the success. Lessons learnt from similar projects implemented in the past are vital clues and the basis for the future and must be reviewed carefully. Competitive strategies cannot be built on major spending programmes but on addressing structural reforms in areas such as business environment, modernizing public administration, important companies' abilities to innovate or enhancing energy efficiency. A Better coordinated vision of policy making at all levels improves functioning. Though China has gone a long way in short time but many challenges and difficulties exist in her way also to sustain the growth. China model offers many lessons in establishing industrial clusters but everything must be seen in the local context. Adaptation to local conditions is very important in preparing and refining the policy imperatives for industrial corridors in India. 'Less of government and more of governance' is the 'mantra' for future.

[1]. indiabudget.nic.in/budget13-14/es2012-13/echap-09.pdf

\section{References}

[2]. Almas Heshmati (2007). A Model for Individual Development of Federal Region of Kurdistan: Science and Technology, Policy Instruments and Institutes. Available on http://ftp.iza.org/dp3213.pdf accessed on 18 May 2014.

[3]. Douglas Zhihua Zeng (2011). How do Special Economic Zones and Industrial Clusters Drive China's Rapid Development? Policy Research Working Paper 5583. p. 22. Available at htpp://econ.worldbank.org, accessed on10 Jan 14.

[4]. Thomas Vietorisz (1968). Industrial development Planning Models with Economies of Scale and Indivisibilities. Regional Science Association papersXV. Land Congress, 1968. Available at www.onlinelibrary.wiley.com/doi/101111/j.1435-5597.1964 accessed on 22 Apr 14.

[5]. Wilfried Vanhonacker (2004). Entering China- An Unconventional Approach. Harvard Business Review on Doing Business in China, Harvard Business School Press, Boston, 2004, p. 107.

[6]. op.cit. Douglas Zhihua (2011).

[7]. Arvind Virmani (2006). China's Socialist Market Economy: Lessons for Democratic Developing Countries! Planning Commission Working Paper No. 5/2006-PC. p. 81

[8]. Ming Zeng and Peter J. Williamson (2004).The Hidden Dragons. Harvard Business Review on Doing Business in China, Harvard Business School Press, Boston, 2004, p. 72.

[9]. DIPP, Ministry of Commerce and Industry, GoI. National Manufacturing Policy,2011. Available at dipp.nic.in/English/Policies/National_Manufacturing_Policy_25Oct2011.pdf. accessed on 24 May 2014.

[10]. Charan Singh (2013). Interview: Economic Growth Cannot be taken as Guaranteed: Need for urgent reforms. An Interview with Dr. A. Virmani, former Executive Director, IMF and former Chief Economic Advisor to GoI. IIMB Management Review, Vol. 25 No 4, Dec 2013, p. 247.

[11]. FIAS (2008), Special Economic Zones, Performance, lessons learned \& implication on zone Development available at www.wbinvestmentclimat.org accessed on 13 Feb 2014.

[12]. Sojin Shin (2014). FDI in India: Ideas, Interests and Institutional Changes. Economic and Political Weekly, Vol XLIX No. 3, Jan 18, 2014. p.70.

[13]. Anand Mahindra (2014). India needs Regulatory templates for transparent capitalism. The Times of India, Aurangabad, Feb 7 , 2014. p. 12.

[14]. Amitab Kant, (2013). Manufacturing to be Key Driver of Industrial Cities:DMICDC. Live Print and Wall Street Journal. 15 Apr 2013.

[15]. Aradhna Aggarwal ( 2007). Impact of SEZs on Employment, Poverty and Human Development. Available at www.eaber.org/sites/default/files/documents/ICR/Aggarwal.2007.pdf accessed on 21 May 14. 
[16]. op. cit. Almas Heshmati (2007).

[17]. op.cit. Amitab Kant (2013).

[18]. Vinay Tyagi et.al. (2007). An Assessment of the Indo-China Special Economic Zones: the Conceptualisation. Delhi Business Review, Vol 8, No.1, Jan - Jun 2007.p. 50.

[19]. DLRP (Draft Land Reform Policy) (2013). Department of Land Resources, Ministry of Rural Development available at http://rural.nic.in/sites/downloads/latest/Draft_National_Land_Policy_July_2013.pdf.

[20]. G.S. Kaura (2014). Infrastructure Sector Looks to Faster Clearances from Modi Govt. The Tribune, Chandigarh. 24 May 14. 